\title{
Mythological Thinking and Archetypes in the Contemporary Bulgarian Nestinarski Ritual Complex
}

\author{
Ana Stefanova \\ Institute of Ethnology and Folklore Studies and Ethnographic \\ Museum (IEFSEM) \\ Bulgaria, Sofia \\ Photographer: Svetlan Stefanov, Bulgaria
}

\begin{abstract}
The paper examines mythological thinking in the contemporary performance of the ancient ritual complex of nestinarstvo in Bulgaria. As the folk tradition is transformed into freshly "invented" forms in the village of Stomanevo, it has been influenced by "external" factors such as individual cultural elements as well as by globalization, in particular easy access to information and the flow of esoteric literature into Bulgaria in the aftermath of communism. The rite is further molded by distinct psychological factors that constitute fundamental and dynamic conditions necessary for the tradition to be preserved and to evolve. This ritual is a living example of a community phenomenon with roots in the collective unconscious and based on archetypal structure. While its "outer" traits may vary, the "core" remains the same, representing a mosaic of universal values anchored in space and time.
\end{abstract}

The paper examines mythological thinking in a contemporary performance of the ancient ritual complex of nestinarstvo in Bulgaria. (1) As the old tradition has been transformed into newly "invented" forms (2), it has been influenced by "external" factors such as individual cultural elements and globalization, represented by easy access to information and the flow of esoteric literature into Bulgaria in the aftermath of the fall of communism. These trends are further molded by distinct internal psychological determinants, which make up basic dynamic conditions required for a tradition to persist and to evolve. Ritual is a living example of

FOLKLORICA 2013, Vol. XVII 
a community phenomenon with roots in the collective unconscious based on archetypal structure; while its "outer" traits may vary, the "core" remains the same: a mosaic of universal values anchored in space and time. The Jungian approach has its roots in the work of many authors including Marcel Mauss (1990), Emile Durkheim (1998), Adolf Bastian (1860) (namely Elementargedanken "elementary ideas," Leo Frobenius (1904) (e.g., his concept "cultural monads") as well as in Jung's own work on archetypes and Völkergedanken "ideas of the folk" (Campbell 1960:112).

After 1989, when the socialist system in Bulgaria collapsed, many cultural and subcultural trends that had not been widespread were introduced. Literature about the occult and "exotic" philosophies as well as practices of the New Age movement such as chiromancy, fortunetelling, astrology, Tarot, and yoga sprang up in the marketplace and in the public sphere. Many "practitioners" of healing, clairvoyance and extrasensory perception and training centers and workshops appeared as well. Over a relatively short period of time, a "natural" process of fusion of the traditional Bulgarian material with these new concepts and forms of expression has occured. The words "energies", "magnetic/torsion fields", "kundalini", "aura", "karma", etc., derived from science and religion, have become common in daily conversation, in the media, and even in traditional (folk) rituals. They have influenced performers, observers and practices alike. While globalization has brought different traditional and subcultural forms from abroad, it is no more than a 'layer' in the phenomenology of the sacred; the need for sacred experience had not disappeared. The Jungian analytical approach deals with the sacred experience by distinguishing a universal core, as both a foundational structure and a dynamic, in spite of variable details in a given communal (folk) phenomena. His theoretical concepts are clearly obvious when one compares a particular ritual in space and time. They also provide explanation about the meaning of ritual activities and objects in them, which, according to his theory, express universal and compulsive structures and dynamics in the psyche. We will explore this approach to a neo-folk nestinarstvo rite as practiced in one region of Bulgaria. Before we begin this analysis, some

FOLKLORICA 2013, Vol. XVII 
background on the history and current practices of this ritual tradition is in order.

\section{Nestinarstvo}

The scholar Michail Arnaudov (Vol. 1 1996: 380) describes the Nestinarstvo ritual as characteristic of the Strandja mountain region and it is performed in nearly twenty Bulgarian and Greek villages in the regions of Bunarhisar, Midia, and Ahtopol on the Black Sea coast and nowhere else in Europe. Arnaudov proposed that the ritual originated in Asia Minor. Slaveikov (1866), who was the first to document the ritual, states that it was also performed in the villages of Kosti, Brodilovo, Blaca, Madjura, Pergoplovo, Rezovo, Murzevo and Agio-Stephano (Arnaudov Vol.2. 1996: 384). As he describes it, nestinarstvo is a ritual complex composed of several different stages. The aim of the ritual is to bring prosperity, ensure health, and to bring an end to war. In the annual agricultural cycle it occurs at the beginning of the summer on the fourth of June, the feast day of St. Konstantin and St. Elena; it takes place throughout the day and into the evening. These facts connect to the solar-chthonic origins of the ritual. The event begins with the gathering of people in the morning in front of the konak (a holy building where the icons and the holy drum are stored yearround). The icons portray the images of St. Konstantin and St. Elena. In folk Christianity this ritual is dedicated to this holy couple. (3) The next stage is a visitation of a holy spring (aiasmo), where the icons of the saints are washed to musical accompaniment (a drum and bagpipes). Participants then walk across the village at the completion this stage to begin another: the sacrifice of a ram, bull or other animal. A wrestling contest ensues between volunteers. When a winner has been declared, finally a feast in the konak for the community at one table and for the main ritual participants at another begins. An icon procession goes from door to door to all the homes in the village. The ritual culminates with fire dancing which is performed outside the village proper, in a place called the gumno (field, place). The ritual complex also includes deciding where the ritual would be performed the next

FOLKLORICA 2013, Vol. XVII 
year. The location is determined by "arranging a meeting" between the two patron-icons of two villages, the icon of the "Old" and the "Young" St. Kostadin (Konstantin) (4), and by knocking them "across." "Across" in this context denotes touching the two icons horizontally, then vertically, so that they form a cross.

The firedancers are said to "catch" St. Konstantin, experiencing "heavenly obsession." The term "catch" means to enter into a trance (in this particular case with the help of St. Konstantin's will). Arnaudov mentions the connection with the ancient mysteries and shamanism in his consideration of the ritual. According to Eliade, entering into ecstastic trance is the most important trait of the shamanic experience. Another important characteristic is control over "magic warmth" (Eliade 2000:17). Both of these traits are well represented in the nestinarstvo rite. Other shamanic characteristics include the ability to heal and tell fortunes, abilities which the nestinari 'fire dancers' also gain. Note that they do not heal directly, but give advice on how one may find a remedy for a particular illness.

During the communist period the process of secularization and desacralization affected most aspects of life, including traditions. The nestinarstvo was limited to only one component, dancing in fire, and was presented in restaurants and hotels on the Black Sea coast as a "trick" in the form of entertainment. These kinds of performances still exist today (see image 1). The focus in these performances was less on the group and on the benefits of the ritual for them, but rather on individual prowess. People in various locales (camps, barracks, gatherings) entertained themselves by trying to walk in the fire. In most of those cases, the experience of fire dancing is distinct from the sacral characteristics of the traditional ritual form as described in prior centuries.

FOLKLORICA 2013, Vol. XVII 


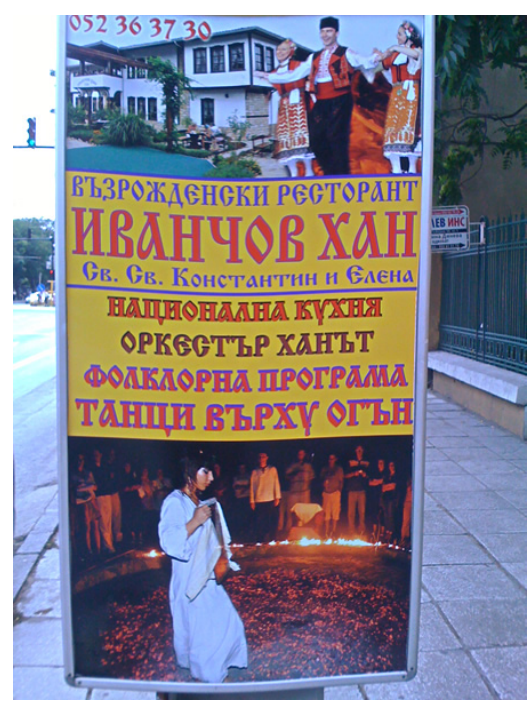

Image 1: A street poster announcing a folklore program including fire dances at a restaurant at the resort "St. Konstantin and St. Elena" near Varna on the Black Sea coast

Over the last dozen or so years, the nestinarski ritual complex has migrated from its traditional location on Stranja Mountain. Now it is performed in a location on the Rodopa Mountain in the village of Stomanevo, where it was not previously attested. Fieldwork performed in this region in 2011 informs us about how the rite and its innovations have been adapted to the contemporary world. I will argue that they cannot be explained unless one considers the universal and compulsive nature of the unconscious and the resultant impetus for mythological thinking.

The population of Stomanevo is about 150 people, largely Bulgarian Muslims. There is also a small minority of Pomaci, Bulgarian citizens of the Islamic confession, who speak Bulgarian natively. They call the ceremony the "nestinarski feast" or "a pagan ritual". The organizer and main performer in this village is Ivailo Aianski, a 41-year-old native of Plovdiv (see images 2 and 3). Ivailo Aianski claims that the ritual he performs is "authentic", with its origins in ancient Thrace 6000 years ago. He once studied ethnology at the university in Plovdiv, but he did not complete his studies. Ivailo is a farmer and stock-breeder; he tends flocks and,

FOLKLORICA 2013, Vol. XVII 
according to one account, his annual harvest of potatoes is nearly 60 tons. He also produces cheese, milk, honey and other organic products.

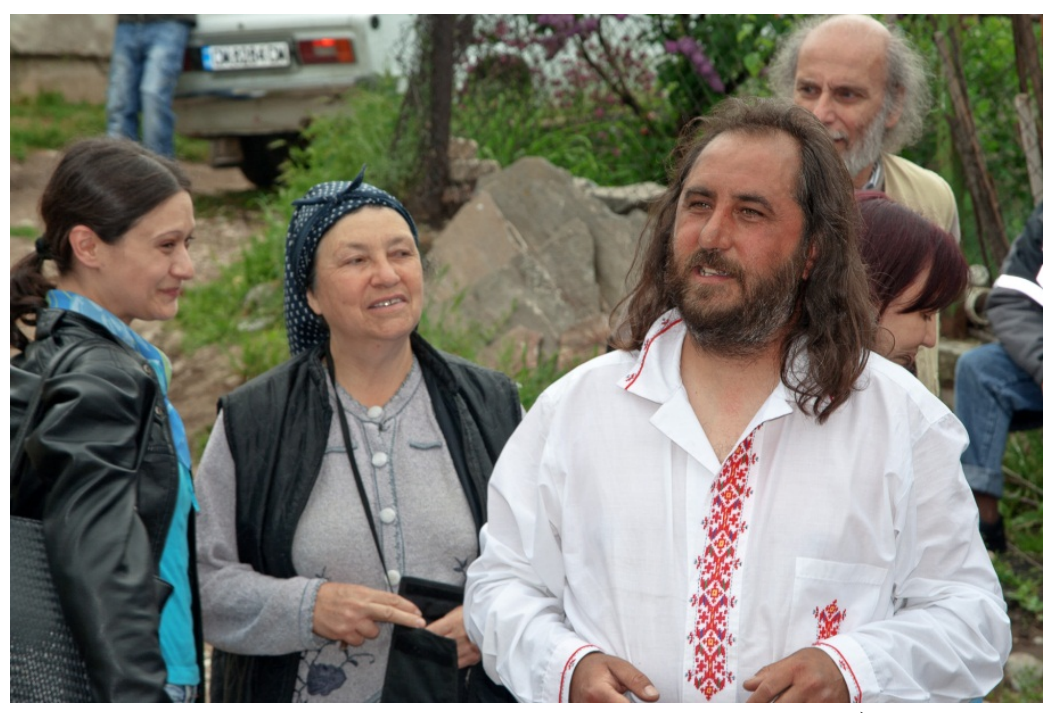

Image 2: Ivailo Aianski and his wife (next to him)

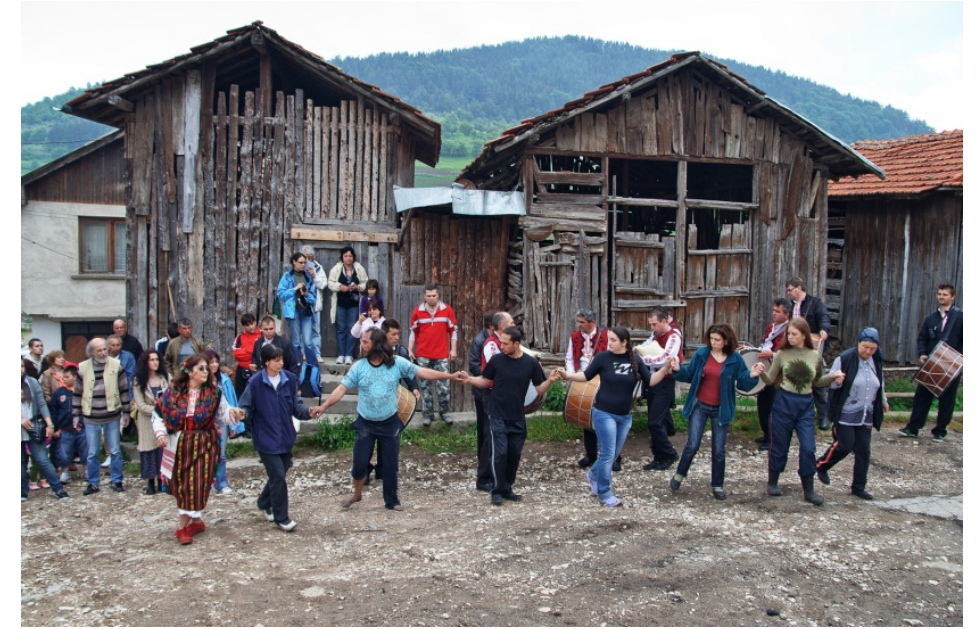

Image 3: Nestinarsko horo. Ivailo in light blue t-shirt, third from left to right

FOLKLORICA 2013, Vol. XVII 
One informant who attends the event every year (Z.V., born 1956, Ivailo's close friend, a journalist and poet and organizer of a visiting group from Varna) attested to Ivailo's power and to the authenticity of the rite: "It was raining the whole time 2 years ago, from the morning on. But he is a wizard; he threw some ashes into the sky, while mumbling some words, and the rains stopped. But at 1 P.M. it started to rain again. It rains on the fire, a smoke rises, but the coals are alive and he dances in the fire. This is his feast; from the beginning to the end he does it as the ancient Thracians had." The description offers a stark contrast to the Strandja ritual, which he called "commercial, only a show." Z.V. went on to describe the benefits of participating in the ritual:

A chain dance (horo) is a dance that is danced all day long. You'll see. It is called"the horo of life". And it is good for you to dance, not only to watch. Around the fire. All the chakras are cleansed, and you ensure that the upcoming year will be good for you. It is an amazing experience; you do not need to sleep on your way back. Very "energizing." But in places that have a great deal of energy a person must be very knowledgeable and know how long to stay. There is a movement from plus to minus. Your own body hints how long to stay, in order for plus and minus to become equal. If you are very "minus," after that to become very "plus," why do you need this? You will feel bad again ... The dancing starts after sunset, when the sun disappears. Once he started earlier, he said he has permission from "Up Above."

Z.V. asserted that Ivailo's power is not only due to his own abilities, but is part of his heritage. He noted that: "a long time ago he visited Strandja, at the time when granny Zlata (5) had been dancing. And when she first saw him, she told him he is good at that and should dance. St. Konstantin is a demagogue in history. His mother Elena was a cunning politician. He also talked about Ivailo's grandmother as a priestess." Her Bulgarian name was Rosana, but she was of Turkish origins and really was named Rufie (see image 4). Ivailo had told Z.V. that his grandmother Rosana was like a goddess to him. She is said to have been the source of the famous phrase of the character from the movie (based on the novel by the Bulgarian author Nikolay Haitov) Men's Times: "First

FOLKLORICA 2013, Vol. XVII 
is to want, second is be able to, third and fourth is to do." Rosana served as a consultant for the film A Time Apart (based on the novel by Anton Donchev, about the Turkish slavery on Rodopa Mountain, her native region). (6)

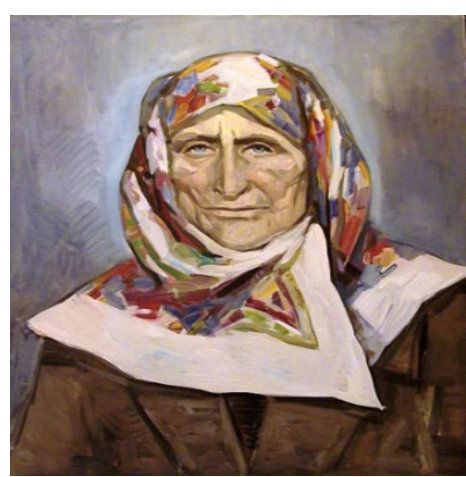

Image 4: Portrait of Granny Rosana by the painter Nikolay Roussev. Sometimes Ivailo dances with it in the fire.

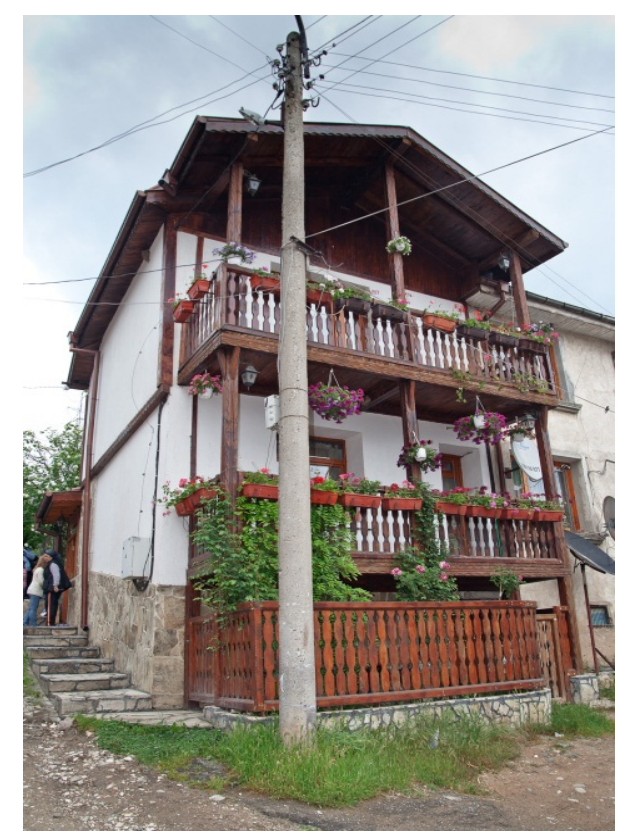

Image 5: Ivailo's house: the beginning point of the riual complex

FOLKLORICA 2013, Vol. XVII 
According to Z.V., some days before the ritual Ivailo feels bad, his "soul flies away" and prepares for the trance. Z.V. explains that by performing the rite: "Ivailo wipes away all the stupid things we have done" and that "the sky opens and energies come down." He helps the sick as well, as Z.V. describes:

Usually he calls the worst cases first, sitting under a tree, talking to them. Once he called an old man whose son was killed in a forest. And he told him that another One (7) will have revenge. But he should go to a tree and dig on his left side and he would find an icon, nearly $40 \mathrm{~cm}$ under the ground's surface. 'And your heart will calm down,' Ivailo said.

It is notable that this fits the description of "shamanic disease" described by Eliade (2000).

Z.V. said that in the last several years Ivailo has slaughtered a sacrificial animal under a large tree in the presence of the visitors and the entire community. The slaughter was not part of the ritual previously in this version of the rite. Only the eating of the kurban ('sacrifice', a sacred meal of meat soup cooked from the sacrificed animal) was characteristic earlier. He explains that first Ivailo talks to the animal, getting in contact with its spirit, asking for permission from the one who will die for the community and then hypnotizes it. It is believed that the next incarnation of the animal will be human and, because of the sacrificial act, Ivailo will be obliged to care for this person.

The group with whom I travelled to the nestinarski feast from Varna contained about 25 people, mostly women. Most of them are "pilgrims," not "tourists." They were non-smokers and typically practiced yoga. Their conversations in the bus were about healthy lifestyles, chakras, energies, holistic massages, Chinese acupuncture and similar New Age topics. One of the women noted that it was good not to eat before reaching the Stomanovo, which is high in the mountains. Another one explained that her turquoise medallion was not hanging exactly in the "hollow of her neck" by chance, but because it protects her.

At the outset, the village did not appreciate or accept this new ritual tradition, but now most of the villagers participate with

FOLKLORICA 2013, Vol. XVII 
pleasure, at least it so appears. This feast starts not from the konak (as it does in Strandja), but from Ivailo's own house (see image 5), which he inherited from his grandmother. On the day I attended in 2011, the feast started at 9 in the morning in front of Ivailo's house. Several drummers (8) and bagpipers were playing loudly. His house is the most luxurious one in the village and had been recently reconstructed. Some of the locals stood and watched, while others helped actively in different ways by cooking for the common feast, or by protecting Ivailo, so that he did not fall during his trance. It was apparent that the trance was not deep. He saw everything, he danced, and at the same time he gave different commands, directing the musicians, the people around him and his relatives, who were next to him the entire time. The atmosphere of the event was numinous. At the 2011 event there were more than 200 attendees, most of whom arrived in their own cars. Most of the people who attended knew Ivailo and were his personal guests. People displayed real delight when they met him and some seemed to worship him (see images 6-7).
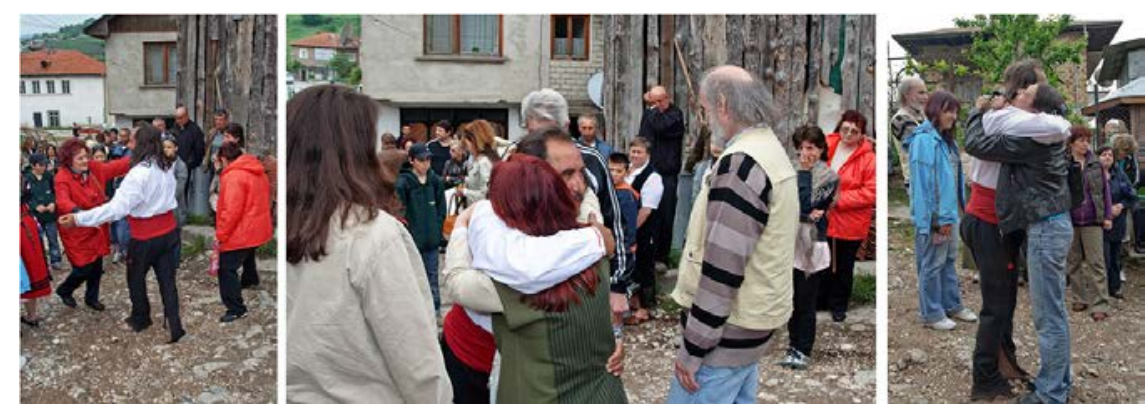

Image 6: Ivailo greeting attendees

FOLKLORICA 2013, Vol. XVII 


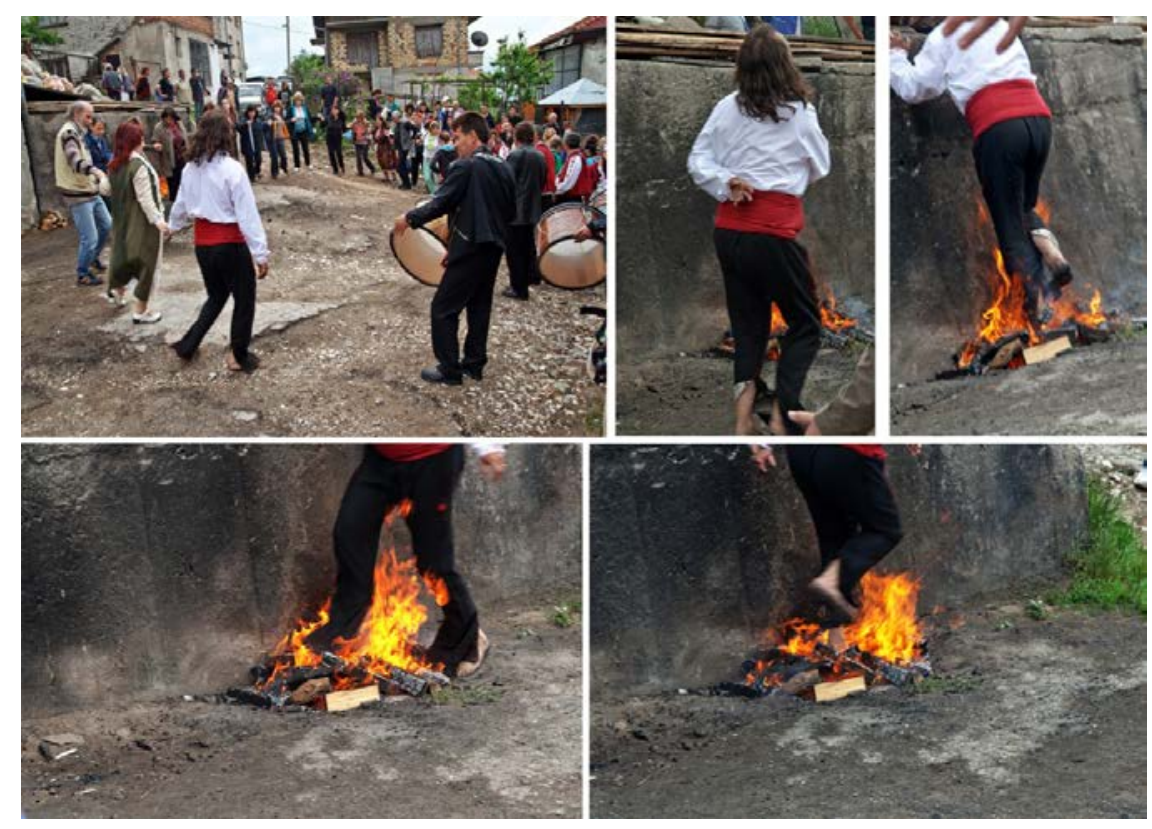

Image 7: Ivailo fire dances by a wall on the village square

Upon emerging from the house, Ivailo asked "Are the parents of Dimitar from Petrich here?" No one answered at first, but then a female helper replied that they had not yet arrived. After a while, these very people, whom Ivailo had expected in his visions, arrived and he invited them into his home for "healing" (by giving advice to them; see image 8).

At that point, he changed his clothes and dressed in a traditional costume. His "manna personality" (9) started preaching (see image 9). A bagpipe quietly accompanied his speech. Sometimes between different topics in his preaching, Ivailo sang traditional (10) songs. He spoke about the roots of the rite, about the happiness of the ancient Thracians when they buried their dead and about the cleansing role of tears. The goal of any person, he

FOLKLORICA 2013, Vol. XVII 


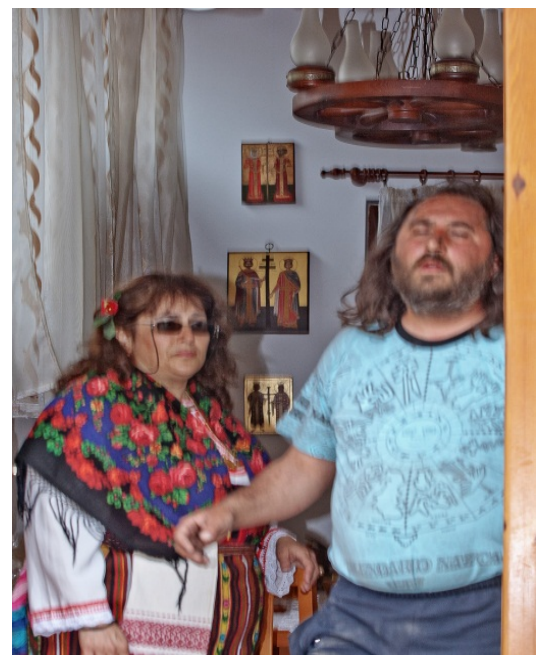

Image 8: Ivailo in a trance, at the entryway of his home, inviting people for healing and fortunetelling. The icons of St. Konstantin and St. Elena are on the wall.
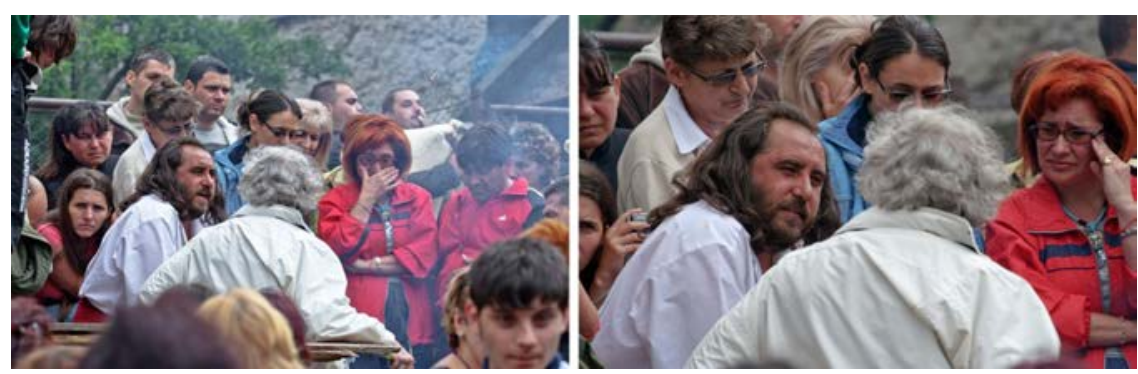

Image 9: Ivailo preaches

says, is to gather himself in unity. He speaks fluidly, almost in rhymes, and some listeners were moved to tears. On the opposite side of the street preparations for the kurban began (see image 10).

FOLKLORICA 2013, Vol. XVII 


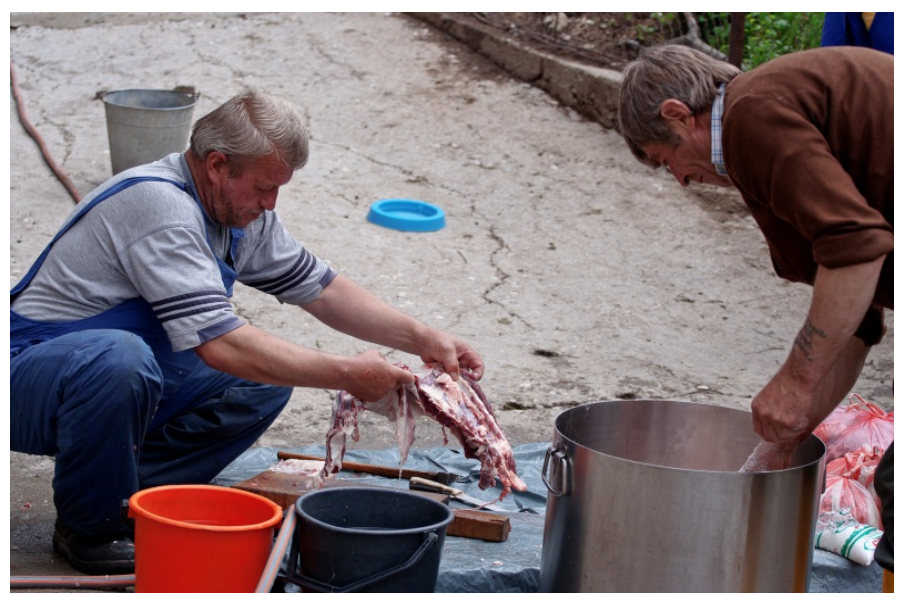

Image 10: Preparing the kurban before the ritual slaughter of the animal, an example for syncretical unity, an example of Wholeness, the "tertium non datur" in Jung's terms; the kurban is neither dead nor alive since the animal is still alive, but the stew is cooking. (11)

At 11.30 A.M. Ivailo was in the house, inviting people in one by one. He declined help to none, and, for that reason, this part of the feast continued until the last person had left his house. He does not accept money. Z.V. said that this year the people in need were much more than they had been in the years before. Ivailo, as nestinar, gives advice on how to solve a particular problem, e.g., by visiting a particular doctor or lawyer who lives in particular town, on a particular street, next to a certain building or location, explaining how exactly to get there. Z.V. said that Ivailo sees things by clairvoyant visions and has never physically visited these places or heard about these experts before. He also said: "there are karma-, genetic- and physiological illnesses." The first two are the most difficult to heal, because they demand a kurban be done. The "physiological ones" can be healed relatively easily, and Ivailo tells them where and how to do this.

The next stage of the ritual complex was the visitation of the holy spring, the aiasmo. The bagpipes started playing again, and the procession exited the house, with Ivailo, his wife, daughter and assistants at the head (see image 11).

FOLKLORICA 2013, Vol. XVII 


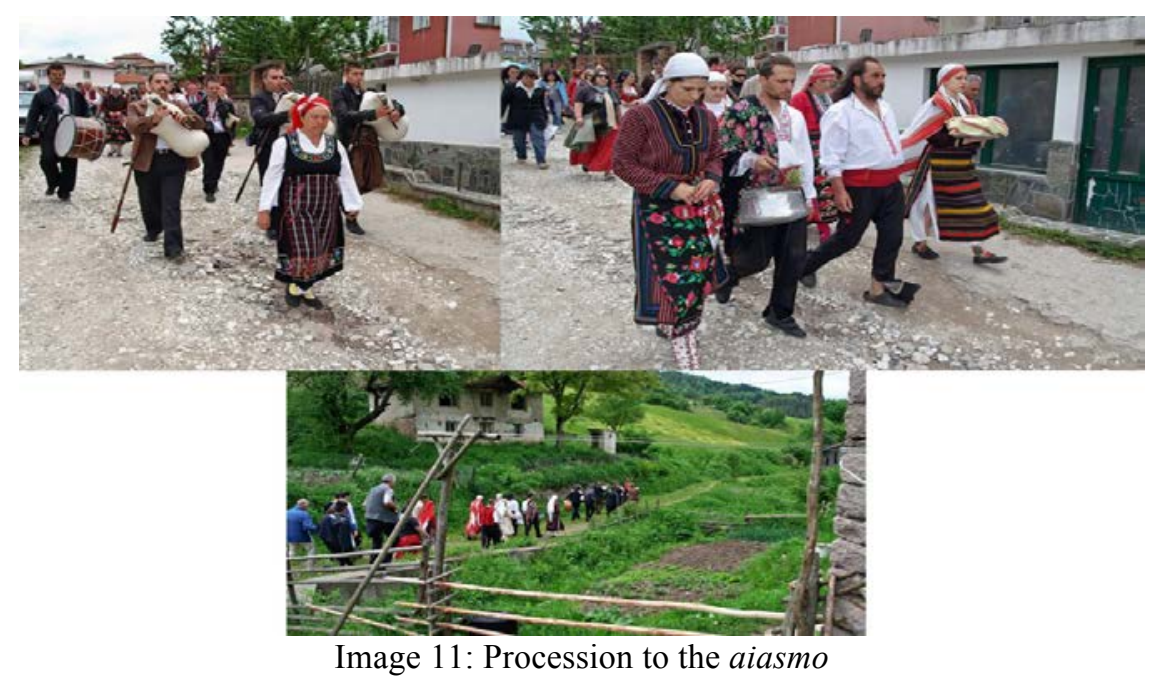

The spring is roughly 5-7 minutes away from Ivailo's house. It is a stone fountain with three pipes with stone plaque, on which is written: "placed in 1985 as a present to the village Stomanevo from the municipality and in honor of Bulgarian-Soviet friendship" (see image 12). The contrast shows the ability of a compelling archetypal form to "fit" well in any kind of content, even one that is not inherently sacred. Because of the dialectics of the sacred and the secular (socialist) object, hierophany paradoxically results, but that does not prevent the object from participating as a sacred item in this context (Eliade 1998:70).

The pipers continued to play throughout this portion of the ritual, as Ivailo wet his hair with water from the spring. Kneeling and bowing, he walked backwards using small steps while pouring water over his forehead. He put pieces of bread broken off a traditional round loaf held by one of his assistants into a trough. Then he dipped a bouquet of yellow forest flowers into a pot of holy water and, with it, sprinkled first his assistants and then the rest of the people around him. He took the wet bread, squeezed it and put it into a hollow of a big yoke elm tree behind the fountain.

FOLKLORICA 2013, Vol. XVII 

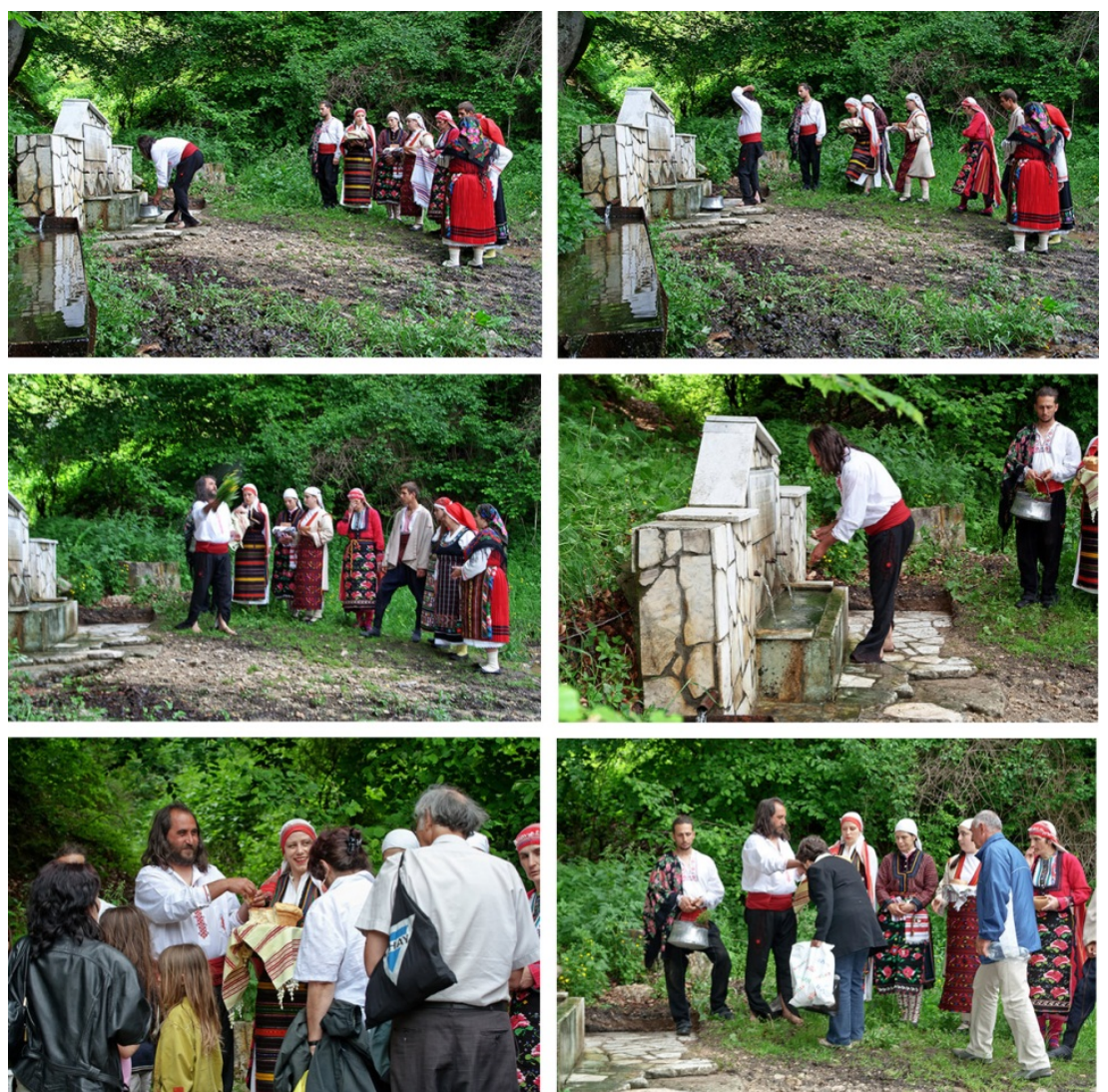

Image 12: The water ritual

Ivailo put a morsel of bread into the mouths of each one of his helpers. They then kissed his hand. After that he did the same to every person in the group. Each person, after eating his/her morsel and kissing Ivailo's hand, stepped aside and washed his/her face in the spring. Ivailo smiled kindly at each person. When the last person in line took part in this stage of the ritual, the procession continued to the glade, where the final stage would occur.

Some of the people did not go on foot, but rather in their cars. Taking into account the vehicles, clothing and the accessories of the visitors, I concluded that the persons were of average or higher social and economic status. Another marker of this status was the conversations during this transition. They used this period between

FOLKLORICA 2013, Vol. XVII 
two ritual acts (12) to make calls on their cell phones. It was a work day, so that there were many attempting to check in to the office at a distance. The conversations contained phrases about the "budget of the miniature model," "marketing research," "functioning of a station relay," "problems on the server," etc. It was clear that they were of different professions, but, in general, were highly qualified professionals. Other conversations among participants were similar to those on the bus, e.g., about how to clean chakras, communication between auras and energy manipulation, all topics characteristic of "New Age" movements.

The final stop of the procession was a glade outside the boundaries of the village at approximately 3:30 in the afternoon. Bagpipers and drummers started to play, and people jumped into a horo. Ivailo sat under an old wild pear tree. At one side of the glade were the cauldrons with the boiling kurban. Near them, the sacrificial ram, a beautiful, dark brown animal, was tied to a pine tree. Various local foods such as yogurt and cheeses were available for sale in the glade. The visitors, most of them from big cities, showed great interest and soon the organic food was sold out.

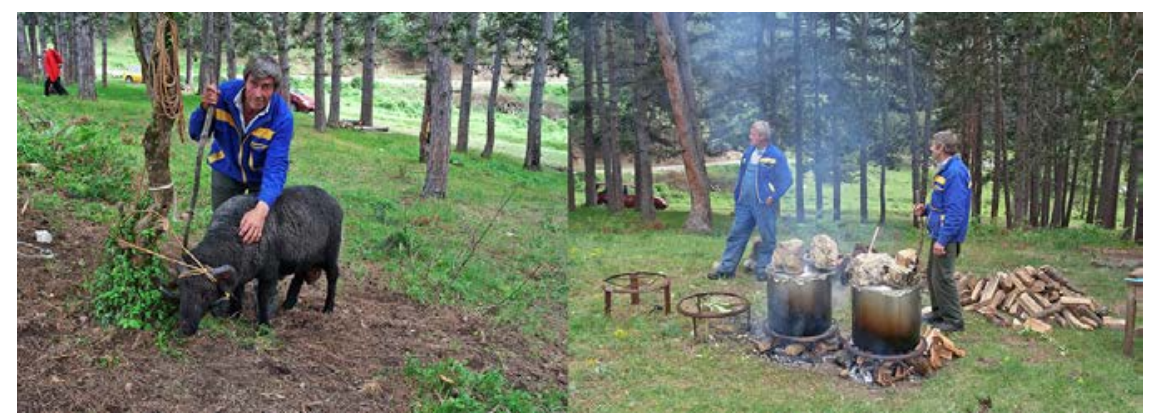

Image 13: The kurban - both alive and cooking

Ivailo was meditating, pressing his palms together in prayer as his gaze wandered. One of the helpers dug a pit in front of him under the tree. Ivailo's wife sat next to him. Young women in traditional clothing were standing behind him, holding the same exact round loaf of bread that was featured in the water ritual. Spices, cooking oil, pieces of cloth, the cauldron and the bouquet

FOLKLORICA 2013, Vol. XVII 
of flowers were placed next to the tree (see images 13-14). The drums beat faster. The butchers, who also did the cooking, brought the ram and laid him on edge of the pit. The crowd was very thick; many whispered: "he is hypnotizing him."

The two men slaughtered the ram. Ivailo held a cloth to the wound and brought the cauldron closer to fill it with some of the flowing blood. Most of the blood ran into the earth of the pit. The nestinar sprinkled the dead ram with the flower bouquet that had been dipped in holy water. At that moment the drums stopped, and a total silence fell. Ivailo stood with dull eyes and leaned his back against the tree. The butchers and some assistants untied the ropes binding the animal's legs and used them to hang it with its head downwards from a big tree branch, preparing it for skinning.

Everyone watched the sacrifice; no one turned away. During the skinning of the animal on the other side of the tree, Ivailo stayed at his place and preached. "Every illness comes from fear and the envy...you should take more humility from life, because you should pay back for what you have taken." He also divined "on clothes," a divination practice for a person who was not present, but whose relatives had brought a piece of clothing (see image 15). The clairvoyant uses it when a person it belongs to is not present to tell that person's future.

He also gave instructions for healing. For example, he gave advice to one person that pinecones and pine branches would be suitable for his illness. Hearing that, another person, an old man, started to shake and knock down the pinecones from the nearest tree, even though the "recipe" had not been directed at him.

Many people arrived for the ritual at this final stage, including the winners of the last two seasons of the television show Clairvoyants, Ivelina Hristova and Mariana Stefanova. As television stars who represent contemporary "mystical" beliefs, they were seeking both popularity and validation by participating in this rite. They also wanted to establish a connection between traditional and innovative ritual forms on the basis of a common archetypal form in two different contexts. There seemed to be a

FOLKLORICA 2013, Vol. XVII 


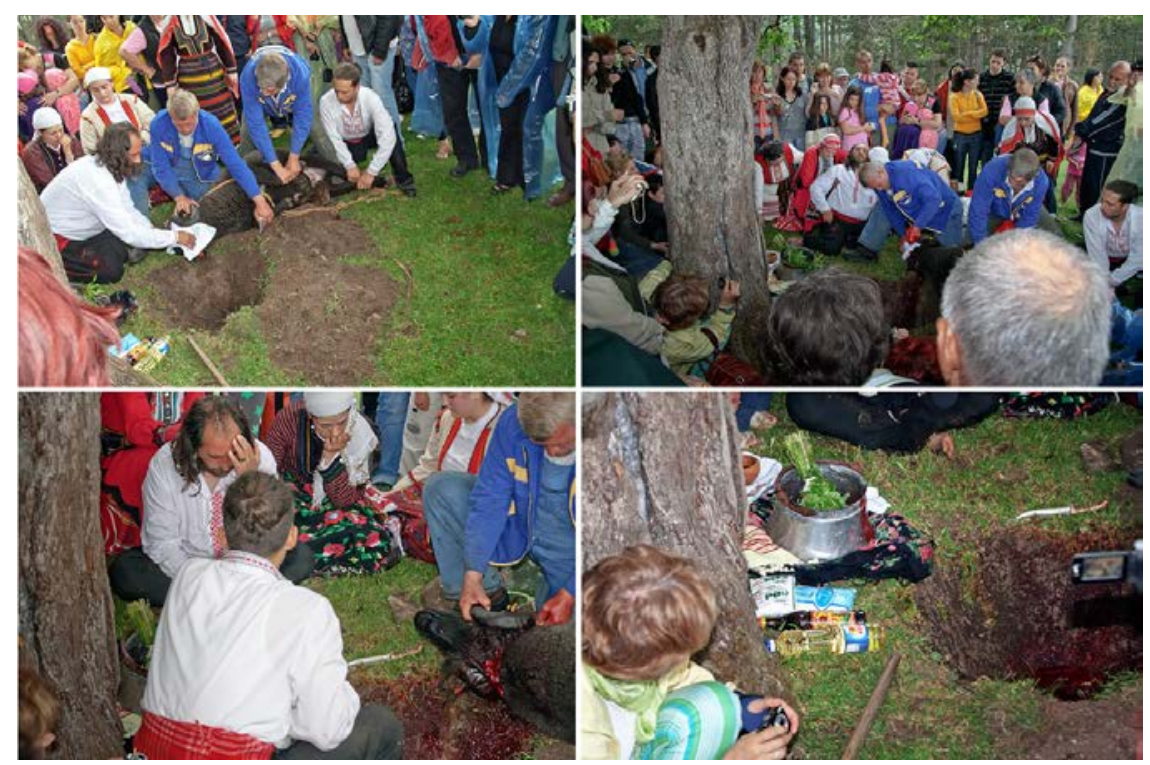

Image 14: The sacrifice
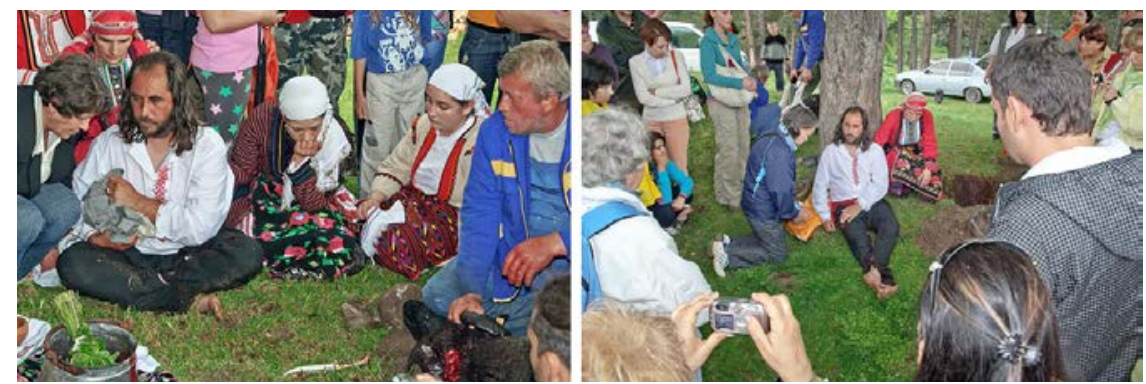

Image 15: Divination

hierarchy; Ivailo preached to Ivelina and not to the other woman. She was there with a crew to shoot a movie about her abilities and personality. Her participation in the "feast" was a part of the production.

The details of the event as an entire complex created by the performers, the "scenario" and the observers, undergo changes over time in each of these ritual components. The ritual occasion attracted people with particular interests, even if they were

FOLKLORICA 2013, Vol. XVII 
eclectic. However, the archetypal symbols are largely the same as those in the traditional ritual, because the dynamics of the psyche demand to be "filled" at a particular time and space. The need for the sacred is most important in our consideration of this innovative tradition. The details in this ritual adapt to these peoples' changing needs and the particular needs of the performer at the same time. Strandja's villages are visited by other people, who are attracted by the details of the Strandja ritual and it meshes with their needs.

At 5 P.M. people were dancing the horo. Some were sitting on the ground, watching and talking. The butchers were cutting the meat of the ram into portions on a table. Nearly two cubic meters of wooden stakes brought by truck were arranged in the center of the glade. They were lit without any accelerant (see image 16).

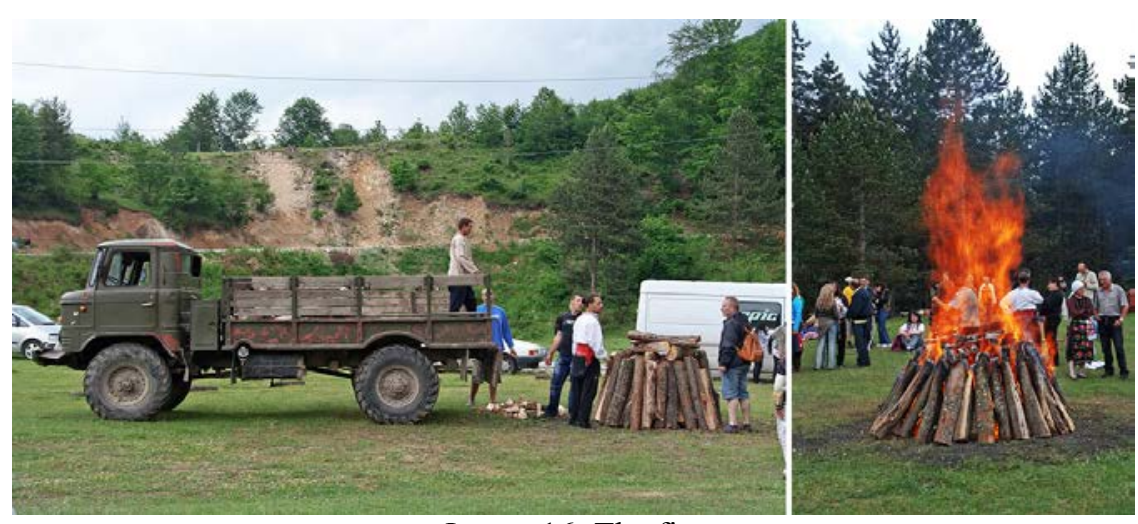

Image 16: The fire

The helpers quickly set up a tent, into which the women placed colorful traditional carpets and carried in provisions, vessels and supplies to prepare the dishes before serving them at the ritual table. Other helpers marked a ring around the fire by forming a 15 meter circle of meter-long stakes. These stakes marked the boundary for the audience. Only Ivailo, his assistants, and the musicians had access to the center of the glade where the bonfire was located. Another group of musicians, in this case Roma, with a drum and two zournas (a kind of clarinet) arrived and started

FOLKLORICA 2013, Vol. XVII 
playing. Ivailo was still preaching under the tree as the wood in the bonfire collapsed little by little.

First Ivailo danced alone, performing the kuchek, a cheerful, emotive, Asian-style dance. He was not in a trance as of yet. Ivelina Hristova (the winner from the first season of the television show Clairvoyants) spontaneously joined in as his dance partner. At the same time the helpers were covering the ground between the playground (gumno) and the Holy Tree (the wild pear) with a white cloth nearly 12 meters long. This served as the ritual table. They placed many cut flowers, particularly lilac and peonies, on it. The women served up round bread, potato pie (a dish specific to Rodopa Mountain, a region famous for its potatoes), onion pie, biscuits, fried dough, etc. No alcohol consumption occurred at any point in the day or at the feast itself. Eventually they served the meat.

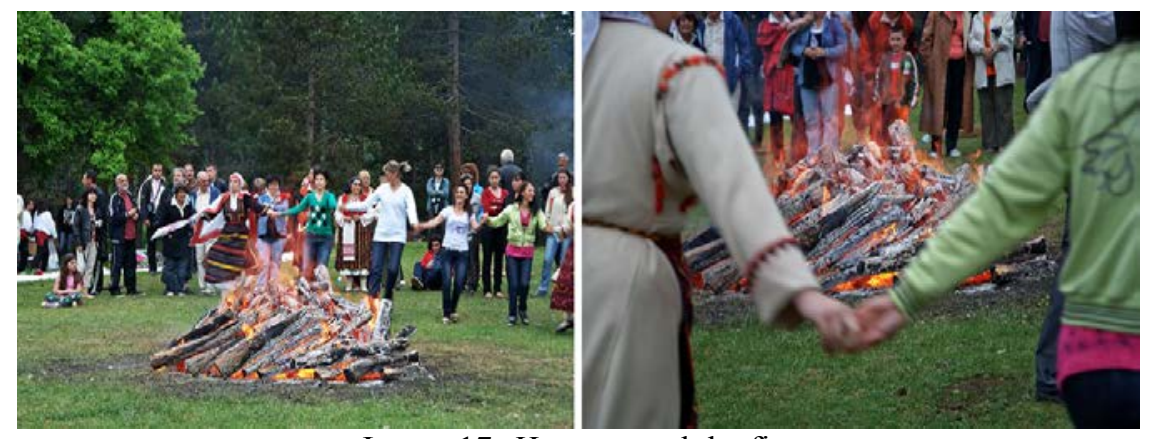

Image 17: Horo around the fire

It started to rain, as it had many times during the day, but it was heavier at this point. The assistants covered the table with a large piece of nylon to protect the food. The music stopped, and the people hid under trees and umbrellas, but did not leave the feast. The visitors threw pieces of paper, on which they have written their wishes in a kind of "e-mail to God" into the live coals of the fire. Ivailo started talking about peace and prosperity, sending thanks to his grandmother, who, as he said, taught him everything. He uncovered the table and invited the people to accept his gift.

FOLKLORICA 2013, Vol. XVII 
At 8.30 in the evening, the rain became heavier, but Ivailo strode into the burning coals, dancing to the accompaniment of the bagpipes and drums. The musicians and people were covered with pieces of nylon or sheltered under umbrellas.

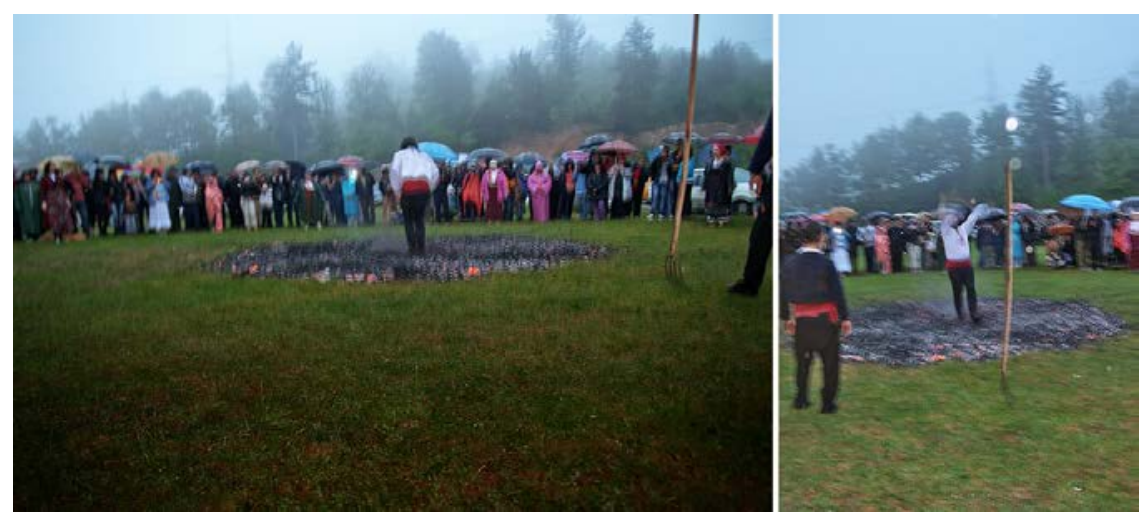

Image 18: Firedancing

He alternated his dance with the horo, which was performed outside of the fire by his helpers (see images 17-18). He marked the shift in dance by giving the musicians a sign to change the music. The "nestinar" music is specific to the fire dance and features the rhythm of the drum alone.

One of the visitors must have shown some doubt about the dancing in the fire, because Ivailo raised his leg high before the person to prove that his foot was intact. The "unbeliever" made a gesture of "protection," nodded his head assent, and clapped his hands as a sign of approval. These acts, it seemed to me, signified an apology of sorts for doubt.

Some people took "new" coals from the fire and returned "old" ones taken from it the previous year. In this way they renewed the fire, initiating a new cycle. A similar ritual exists in other cultures; there is also a traditional Bulgarian folk practice called "renewing the fire" (not connected to nestinarstvo). (13) The rain became increasingly heavy and, by 9 , people were leaving the feast quickly.

FOLKLORICA 2013, Vol. XVII 
Mythological Thinking, the Psyche and Universality

In general, we can conclude that this ritual has a structure common to other rituals as expressed in its archetypal traits. Easily recognizable are traits of mythological thinking in general, for example in the worship of natural elements (water, fire, earth). (14) Contemporary elements and commercial traits, however, are "entangled" with the tradition. (15) In the traditional form of the ritual complex, the main stages of the initiatory process are easily observed. The regression of the conscious comes with the anticipation of the saints' day. In Strandja it is customary for the entire region to visit the "Big Aiasma," a place outside the villages, in the forest, near a holy spring, a week before the saints' day. There they name new nestinars, prepare the icons for the feast, putting them on special "thrones," chairs on which they put the icon among four rods on the seat. Three of these rods they call male while one of them is female. From the point of view of analytical psychology, this quaternity expresses Wholeness, the Self and the Hieros Gammos. As pre-ritual actions, these could be considered as the upcoming Wholeness that emerges from participation in the rite. According to Jung, Wholeness is primordial and, at the same time, it is an aim of existence. The hierogamy, representing the Self, appears also in the presentation of the water, the holy spring, and of fire in the form of bonfires lit in front of the icon "thrones." Other factors helping the regression of the consciousness are the music (especially the drums), the timing (at night), and the contemplation of the icons and the fire.

Another representation of the hierogamy includes the male and female images of the saints in the traditional form of the ritual; the integration of the dichotomies of fire and water, which, in the traditional form, "become one" in space and time on the way from the konak to the gumno; the integration of the saints (the icons) and the multitude; the gathering at the table; the process of the "catching," e.g., the unity of the nestinar and the saint. The daytime period of the traditional ritual also presents an integration

of dichotomies between the day and night. The moment containing the freewill sacrifice integrates the kurban, the nestinar's fire

FOLKLORICA 2013, Vol. XVII 
dance, the burning wood in the fire. Progression is expressed in the final stages by the festive mood; the dances; the table; "nonburning" in the fire; and the expectations for prosperity and fertility. The universal pattern of the initiation, as an archetype of transformation, appears in this new form of the nestinarski ritual as it does in other traditional rituals. In the Jungian approach, it presents and shapes psychological dynamics that appeared in the activities.

In the nestinarski ritual complex we see similar traits to those in Meletinsky's study of myth, which is not surprising as ritual can be viewed as a living form of myth. This ritual demonstrates, in syncretic unity (1995: 5) Meletinsky's three main mythic characteristics: (pre-) science, religion (serving as nuclei of philosophical and religious concepts), and aesthetics. The first two characteristics are represented by the worship of Saints Konstantin and Elena; the concepts of karma; metempsychosis; the connections among the elements, the spiritualization of Nature (animism) and the micro- and macrocosm (the individual and the world (nature, cosmos); the concept of Manna; the power of the ancestors, etc. Aesthetic traits (unconscious poetic creation) are recognizable, too. According to Jung (Samuels, Shorter, Plaut 1995: 162-163), a symbol should not necessarily possess aesthetic meaning; as a part of the sacred context of its own cultural background people experience it isolated from this particular value. However, for the outside observer, who is from another time and culture, different details of the ritual might bring aesthetic experience to the fore, e.g., the music and dances, the traditional costumes, the images of the icons, the portrait of Granny Rosana, the decoration of the table, the meals and the dishes, the colorful carpets, etc. The symbolic act of putting the wet bread into the tree-hollow in the water ritual stage could be considered as homological to the aim of the ritual provision of wellness and fertility. The hands of a person and the person himself could be viewed as a source of fertility and the bread as a fruit in the hollow of the tree as a hypostasis of the womb of nature. From this moment "the womb of nature" is no longer empty; it is fertile, giving bread and life. The symbolic meaning of the sprinkling with

FOLKLORICA 2013, Vol. XVII 
the bunch of the forest flowers could be viewed in a similar way as an act of fertility. The putting of the morsel of bread into the mouths of each one from the multitude may be considered symbolically identical to the previous action of putting the bread into the hollow of the tree: hence the Person and the Tree (of Life) become one, the Person is involved in the life-death-life cycle, in the unity of the micro-, mezo- and macrocosms. The table as a stage of the ritual performs the element of the Earth. The "table" is also a symbol of the Cosmos, the unity, the connection between "our" and the "other" world; the eater and the eaten; the man, the higher power, the animal, the plants; the status of liminality, the whole "concept of the Gift." As a symbol, its meaning cannot be "brought out" fully in one's consciousness; according to Jung a symbol is endless. The symbolic aspects of Fire, based in mythological ideas, could be separated provisionally into several groups of dichotomies: Fire is a mediator between the Worlds, ensuring a rapid connection and is apotropaic, a border between them as well; eyewitness and judge, destroyer and fertilizer.

The ritual may thus be characterized as one of intiation within the cycle of life-death-life. The tree next to the gumno could be seen as a symbol of the Axis Mundi, the World Tree.

This tree and the ritual site together could be viewed as a representation of the vertical and horizontal structure of the world. Note that initiation as used here is derived from concepts in analytic psychology. In this context, initiation denotes a universal psychological process that finds expression in communal phenomena. It can be (only provisionally) separated into stages that appear as "steps" in a ritual. Initiation is realized when a person dares to act against his/her natural instincts and allows $\mathrm{him} / \mathrm{herself}$ to move into consciousness. In general, in this rite, these steps include: 1. Regression of the conscious mind (the "catching" in the nestinarstvo); 2. Sacrifice of one's own free will (dancing in the fire, kurban); 3. Integration of dichotomies (the male and female saints; the integration of water and fire; the man, the animal, the trees, the water, the fire and the saints; the table as a form of introjection and integration); 4. Transformation (to tertioun non datur); 5. Progression of the conscious (end of the

FOLKLORICA 2013, Vol. XVII 
ritual, returning to the profane world); 6. Establishing a new, higher level of existence (expectations for wellness and fertility).

Initiation is related to archetypes of transformation, which Jung defines as non-personalized constructs about situations, modes, means for transformation, ensuring development and change; they are "expressed in many of the situations, places, objects and events reflected in our dreams and lead to corresponding motifs in folklore" (Corsini1998:81). Following Eliade, Campbell and others, we can see space has been conceived as a tripartite entity, represented here as the pit in the ground, the people and the Tree and the "higher power" that "catches" the firedancer. These three spaces parallel the three dimensions of the Cosmos: Under-, Middle and Higher Worlds. The ritual renews the multilayered connection among them and integrates the micro- (the person), meso- (the community) and macrocosms. The idea of metempsychosis and karma, and the unity in the Cosmos (an idea that expresses the universal process of initiation, the cycle of lifedeath-life) in this rite. Common symbols of initiation and transformation are easily recognizable in the practices characteristic of the rite, including: the visitation of the aiasmo (the holy spring); the sacrifice of an animal, the primordial source of life (16); the horo, a circle representing life and transition; the movement between the different stages of the ritual accompanied by certain types of music and instruments (drum and pipes); the common table which expresses a means to integrate the micro- and the macro-levels and which represents transformation; divination and healing; and trance, ecstasy, and fire dancing itself.

This neo-folk tradition also contains aspects of an ancestor cult. The konak has been replaced by the house of the grandmother and the icon of the saints by her portrait. The women's images (Granny Rosana, Granny Zlata, Vanga, Mother Teresa, St. Elena) are aspects of one archetype, namely the Anima of Ivailo Aianski. The Anima is the archetype that makes the connection between the I (Ego) and the unconscious mind; she is a psychopomp. In this context, she helps him enter the trance. The relationship with these famous legendary women increases the importance and the sacredness of Ivailo himself as a Manna personality. Note that only

FOLKLORICA 2013, Vol. XVII 
Ivailo dances in the fire. This is "his" feast. Not even his daughter participates in the firedancing, while in the traditional ritual in Strandja, everyone who wants to, even visitors, are welcome to dance. The rite thus has an established hierarchy: the highest is the Manna person, Ivailo, after whom come the helpers, believers and close friends, essentially his "apostles." This represents a type of cult to a particular person who has inherited his power. This contrasts to the traditional hierarchy in of the rite Strandja, where the saints have more importance than the performers, since it is their feast, and is indicative of how the contemporary rite in this village has evolved from the original.

\section{The Present Preserves the Past}

The compulsive nature of the psyche guarantees the universality of "ritual behavior" based on common traits of mythological thinking and ritual models. The physical presence of facts about any culture in historical documents is not enough justification for their preservation into the contemporary world. A tradition lives on, with its roots in the unconscious, but it is dependent on the creator, the product and the observer (17), three factors that vary in time and space. Each ritual presentation is a reproduction of the tradition, an "original," created again during each performance. Like biological entities, rituals are hereditary and mutable. Even in conservative contexts there exists "dissent," which increases as time passes. In contemporary Bulgarian culture (and other such contexts), these processes of change are rapid and multidimensional, and invented traditions may arise. In spite of the variety of the "inventions," there exists a continuity in the structures of these new rites when compared to older traditions. I contend that they are the result of the unconscious mind and the dynamics of symbol creation derived from the relatively constant physical and temporal environment as humans experience it, e.g., as humans, we are all aware of the presence of certain celestial bodies, of the four elements, of the structure of the calendar as connected with the (agricultural) cycle and its important "high" points (solstices, equinoxes, etc.) as well as of the dichotomies

FOLKLORICA 2013, Vol. XVII 
(universal in their existence and manifested in many cultures) of male-female, day-night, etc. While the pre-conditions of the ritual are found in the psyche, environment and the cultural background certainly contribute to its shape as well, providing a context for its expression. Specific information about ancient ritual practices is not often available, but we can hypothesize that new ritual forms, structures or traditions may appear on the basis of "survivals" (18) or de novo. What is essential in the latter case is not conscious thought or study, but spontaneous action without any necessary analogy to previous practices. The universality appears not in the details, which can vary, but in the essential structure of the ritual, which is presented and experienced by the participants as sacred. None of the main structural components that trace the archetypal structure and ritual dynamics disappear during the migration of a ritual form through space and time.

Groups such as those described here, who practice rituals and create traditions, should be distinguished from those which have the aim of performing the past literally according to a "template." The latter are created as a result of education and study of folklore and are preserving a tradition authentically to the fullest extent possible. I contend that their goals and those who create a neo-folk rite spontaneously are different even though, in both cases, a ritual is performed. The difference between them is analogous to that between the documentation of and creation of history. It is the case that the system and the observer and the performance and its perception are inextricably bound. Even a so-called "absolutely authentic" tradition (as practiced at one time in the past), wellpreserved and performed exactly, is nevertheless now received and interpreted by contemporary people. This fact alone seriously alters the performance and its meaning; the same action in another social context must be interpreted differently. For an observer of a rite such as the one described here, interpretations of culture are primarily aesthetic. They may be seen as an art form, a dramtic role, or a cultural inheritance, but not as an "authentic" part of life. With the inevitable alteration of the components in the system that result from this attitude, a tradition may thus be termed "invented."

FOLKLORICA 2013, Vol. XVII 


\section{NOTES}

1 Nestinarstvo is a ritual complex, because it has a compound structure: stages with various parts integrated into a whole.

2 The concept "invented tradition" is taken from Eric Hobsbawm (1992).

3 The locals view them as mother and son, brother and sister and/or husband and wife; in psychological terms this union of the male and female principle in in every aspect and at once (because the unconscious reconciles the contradictions between them) represents the concept of hieros gamos. (Greek, 'sacred marriage').

4 In the language of the common people.

5 A famous Bulgarian nestinar, a fire dancer from Strandja Mountain.

6 "She raised him. This grandmother was a very close friend of the prophetess Vanga". Z.V. also mentions that Granny Rosana had Albanian ancestry from the line of Mother Teresa. Rosana could control the weather, if she was angry at someone from the village or if someone had done bad things, she had been able to raise a storm and punish the village. In these cases the villagers run home and shut the windows. Her "personal tree" was the fir-tree and sometimes when she was walking through the forest, the fir-trees would bow to her. "Ivailo doesn't dance with an icon, but with his grandmother's portrait, the ones that Nikolay painted", Z.V. continued. Z.V. had recommended that the artist Nikolay Roussev come to Stomanevo to paint a portrait of Ivailo.

7 He did not specify if this expression refers to God; in the author's opinion it seems to refer to, a primal universal force.

8 In contrast, in Stranja there is only one holy drum, which is kept in the konak year round, and people use it only on the day of the feast. Some say that sometimes at night they hear it to beat by itself in the konak. It has the power to heal. The rhythm helps entering into the trance, for "catching," along with the contemplation of the icons and bodily movements, as with typical

FOLKLORICA 2013, Vol. XVII 
shamanic experiences. There are no data on using any other means or substances to enhance "catching".

9 Manna is a Melanesian word for supernatural force possessed by some individuals, objects, actions or events. Its contemporary equivalent is "charisma." This person is a mediator between the worlds of the sacred and profane and communicates with "higher powers" (Samuels, Shorter, Plaut 1995: 94-95).

10 The content of the performed songs is not connected with the nestinarstvo. As it is in Strandja, the music and the songs are not specifically on one topic or for this rite alone, except that they have appropriate rhythm and the melody for entering the fire.

11 This practice is not a contradiction, but is loaded with symbolic value and is well-integrated in mythological concepts (and in rituals). It represents the mythological motive for the "magical cauldron," which renews the "victim" in the neverending cycle of life-death-life, beyond time and space at any singular instance. From the Jungian point of view this could be seen as an expression of mysterium coniunctionis, e.g., reaching the Self by integration of dichotomies. Life-death-life is a cycle among "poles," not initiational acts.

12 In the past, this passage had not been "free" of ritual meaning. The "Way" has its own symbolic aspects and brings specific experience; at the same time it expresses particular psychological dynamics - status of liminality, transformation and integration as steps to the aim of the ritual. "The classical folklore" is a concept about the village community in the Middle Ages. With the disintegration of the patriarchal relationships (from the Enlightenment till now), its wholeness and relative reticence as a system suffers desintegration" (Georgieva 1990: 10). According to Jung, as the conscious mind evolves, "our times differ from any other time" (2002: 179). He discusses the interactions between the individual and the collective psyche and the process of individuation (2004). The psyche finds objectivation in the actions; it means that the culture is a form of expression of it. The combination of "folklore" and the "post-folklore" culture could find explanation from a depth-psychology point of view, in which

FOLKLORICA 2013, Vol. XVII 
the evolution of the conscious and the way it communicates with the unconscious remains intact.

13 For example, the Chinese Po-Sing-Tai-Te, "The Great God, the protector of life" (Arnaudov Vol.2 1996: 386).

14 "For the earliest Greek philosophers, the $\alpha \rho \chi \alpha$ were, for instance, water, fire, or what they called $\alpha \dot{x} \varepsilon \rho \circ v$, the "Boundless". They were not "causes," therefore, but rather primary substances or primary states that never age, can never be surpassed, and produce everything in the world. They function the same way in mythology. They form the ground or foundation of the world, since everything rests on them. They are the $\alpha \rho \chi \alpha i$ to which every individual thing returns and out of which it is made, while they remain ageless, inexhaustible, invincible in timeless primordality, in a past that proves imperishable because of its eternally repeated rebirths (Jung \& Kerényi 2002: 8).

15 There is an English saying: "Where there is a pilgrimage - there is a market." The traditional entanglement of the profane and the sacred and the coexistence of sacred event and market in same time and place have been the subject of interest by scholars such as Anna Wessman (2009:16).

16 According to Jung, the symbol is not a sign. This means, that it presents much more than the "obvious". The culture gives only "outer" traits for the universal core, of the archetype. The unconscious component of the symbol is the reason it to be experienced universally in space and time. Franz Cumont (1999; 136), for example, describes that the sacrifice in Mithraism is an obligation of the priest and the blood of the victim is collected in a pit in the ground. The sacrifices of living creatures, according to the author, are about daemons. The Tavrobolia is connected with the ideas of purification and immortality, and rejuvenation in all aspects of life. The basic concept is that the blood contains "living energy" that may be transferred. Examples can be found in many different cultures. In this particular case, in nestinarstvo, they outline the solar-chthonic nature of the cult and the aim for integration of the opposites, transformation and rejuvenation or the stages of the initiation.

FOLKLORICA 2013, Vol. XVII 
17 This topic merits more consideration, but is beyond the scope of this analysis.

18 A concept based on Edward Taylor (1873).

\section{BIBLIOGRAPHY}

Arnaudov, Mikhail. 1996. Арнаудов, Михаил. Очерųи no българския фолклор. [Essays on the Bulgarian folklore]. Т.1. София. Академично издателство "Проф. Марин Дринов”.

Arnaudov, Mikhail. 1996. Арнаудов, Михаил. Очеризи по българския фолклор. [Vol. 2 Essays on the Bulgarian folklore]. Т.2. София. Академично издателство “Проф. Марин Дринов".

Bastian, Adilf 1860. Der Mensch in der Geschichte. 3 vols. Leipzig.

Campbell, Jozeph. 1960. The Masks of God: Primitive Mythology. London. Secker \& Warburg.

Corsini, R. 1998 (1987). Корсини, Реймънд 1998: Енциклопедия психология. София: Наука и изкуство. [Encyclopedia of Psychology], 1987: Wiley: Interscience.

Cumont, Franz. 1999 (1913). Кюмон, Франц. Мистериите на Muтpa. [The mysteries of Mithra], София. Издателство “Шамбала".

Durkheim, Emile. 1998 (1915). Дюркем, Емил. Елементарни форми на религиозния живот. [The elementary forms of religious life ], София.

Eliade, Mircea. 1998 (1952, 1991). Елиаде, Мирча. Образи и символи. Размисли върху магическо-религиозната символика. [Images and Symbols], София: Прозорец.

Eliade, Mircea. 1999 (1976). Елиаде, Мирча. Митове, сънищза, тайнства. [Myths, Rites and Symbols], София: Прозорец.

Eliade, Mircea. 2000 (1955). Shamanstvo (Shamanism). Елиаде, Мирча. Шаманизмьт и архаичните техники на

FOLKLORICA 2013, Vol. XVII 
екстаза. [The shamanism and the archaic thechnics of the extase], София. Издателство ЛИК.

Eliade, Mircea. 2000 (1969, 1984) Елиаде, Мирча. Търсенето. История и смисъл в религията. [The Quest: History and Meaning in Religion], София. Издателство ЛИК.

Frobenius, Leo 1904. Das Zeitalter des Sonnengottes. Berlin.

Georgieva, Albena 1990 Георгиева, Албена. Етиологичните легенди в българския фолклор. [The Etiological Legends in the Bulgarian Folklore], София. Университетско издателство “Климент Охридски".

Hobsbawm, Eric, Terence Ranger, 1992. The Invention of Tradition. Cambridge University Press.

Jung, C.G. 1999 (1981). Юнг, Карл Густав. Архетипите u колективното несъзнавано. [The archetypes and the collective unconscious], Плевен: ЕA.

Jung, C.G. 2002 (1933, 2001, 2005). Юнг, Карл Густав. Съвременният човек в търсене на душата. [Modern Man in search of a Soul], Плевен: EA.

Jung, C. G., C. Kerényi 2002: The Science of Mythology. Abingdon: Oxon. Routledge Classics.

Jung, C.G. 2004 (1953). Юнг, Карл Густав. Две студии nо аналитична психология. [Two Essays on Analytical Psychology], Плевен: ЕА.

Mauss, Mauss. 1990 (1922). The Gift: Forms and Functions of Exchange in Archaic Societies. London: Routledge.

Meletinski, Ieleazar. 1995 Мелетински, Елеазар. Поетика на мuта. [Poetry of the myth], София: ИК “Христо Ботев”.

Samuels, Andrew. Shorter, Bani. Plaut, Fred. 1995 (1986). Самюелз, Андрю. Шортьр, Бани. Плаут, Фред. Критически речник на аналитичната психология. [А critical dictionary of Jungian analysis], Плевен: EA.

Tylor, Edward. 1873. Primitive Culture. London.

Wessman, Anna 2009. "Iron Age Cemeteries and Hiisi Sites: Is there a Connection?" Folklore - Electronic Journal of Folklore, Vol. 42, Department of Folkloristics at the Estonian Literary Museum.

FOLKLORICA 2013, Vol. XVII 
Z.V., DOB 1956, journalist/poet, native of Varna, interviewed June 2011 in Stomanevo.

FOLKLORICA 2013, Vol. XVII 